\title{
Evolution and presence of diurnal predatory birds in the Carpathian Basin
}

\author{
Jenő (Eugen) KESSLER
}

Received: February 05, 2018 -Revised: May 03, 2018 -Accepted: May 08, 2018

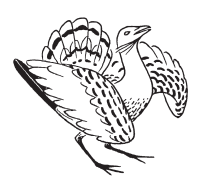

Kessler, J. (E.) 2018. Evolution and presence of diurnal predatory birds (Ord. Accipitriformes, and Falconiformes) in the Carpathian Basin. - Ornis Hungarica 26(1): 102-123. DOI: 10.1515/ orhu-2018-0008

the world and fossilized representatives of different families, as well as the presence of recent species in the Carpathian Basin among fossilized remains. In case of ospreys, one of the oldest known materials is classified as a new extinct species named Pandion pannonicus. The text is supplemented by a plate and a size chart.

Keywords: birds of prey, evolution, Carpathian Basin, Osprey, eagles, buzzards, vultures, falcons, Pandion pannonicus sp.n.

Összefoglalás A szerző bemutatja a nappali ragadozók kihalt fajait és a különböző családok fosszilis képviselöit, valamint a recens fajok Kárpát-medencei jelenlétét a fosszilis maradványokban. A halászsasok között itt kerül elöször leírásra egy új faj is (Pandion pannonicus), amely egyben az egyik legrégebbi is az eddig ismert anyagokból. A szöveget egy ábra és egy mérettáblázat egészíti ki.

Kulcsszavak: ragadozó madarak, evolúció, Kárpát-medence, halászsas, sas, ölyv, keselyü, sólyom, Pandion pannonicus sp.n.

Department of Paleontology, Eötvös Loránd University, 1117 Budapest, Pázmány Péter sétány 1/c, Hungary, e-mail: kessler_jeno@yahoo.com

\section{Introduction}

Accipitridae is the most populous family in terms of species (eagles, goshawks, kites, harriers and vultures belong in the group). Their oldest representatives are known from the Eocene of England (Palaeocircus cuvieri Milne-Edwards, 1871) and Germany (Messelastur granulator Peters, 1994), while the other extinct genera and species are known from the Oligocene (Aquila hypogaea Milne-Edwards, 1892; Milvus deperditus Milne-Edwards, 1871, France, Buteo grangeri Wetmore and Case, 1934, USA) and the Miocene (Halliaetus piscator Milne-Edwards, 1871; Aquila depredator Milne-Edwards, 1871; A. pennatoides Gaillard, 1939; A. prisca Milne-Edwards, 1863; Milvus incertus Gaillard, 1939, France). From the Eocene and Oligocene of France Plesiocathartes europaeus Gaillard, 1908; P. kelleri Mayr, 2002; Paleohierax gervaisii (Milne-Edwards, 1863); from the Miocene of Spain Plesiocathartes gaillardi Crusafont and Villalta, 1955 and Neophrontops ricardionsis Rich, 1980 species from the Miocene of the USA are regarded to be the earliest reports of Old World vultures. Recent species are known since the Quaternary.

Ospreys (Pandionidae) are only presented with one cosmopolitan extant species. A typical feature is the special shape of their distal phalanges, which are unlike any other. Their 
earliest forms are reported from the Oligocene of Egypt and Hungary (Máriahalom) (Pandion sp. and Pandion pannonicus n.sp.). Two fossil species were identified from the Miocene of the USA (Pandion homalopterus Warter, 1976; P. lovensis Becker, 1985). The recent species is known since the Quaternary.

The only recent species of the Sagittaridae lives in the Savannahs of Africa. They have especially long legs and prey on smaller vertebrates, mainly snakes. They nest on the crowns of trees. Their fossilized finds are thought to be the species Pelargopappus magnus (Milne-Edwards, 1868) and Amphiserpentarius schlosseri (Gaillard, 1908) from the Oligocene and Miocene of France. Recent species are known since the Quaternary.

New World vultures (Cathartidae) live in America. Their earliest extinct species have been reported from the Oligocene of the USA (Phasmagyps patritus Wetmore, 1927), the Oligocene of Brasil (Brasilogyps faustoi Alvarenga, 1985) and the Miocene of the USA (Hadrogyps aigiloeus Emslie, 1988), apart from numerous other extinct species from the Neogene and Pleistocene. Recent species are known since the Quaternary.

Members of the Falconidae are the swiftest diurnal predators, with typical narrow wings and a toothlike formation on the upper edge of their beaks. They are also capable of "smashing" flight. Their fossilized finds are rare, the earliest one is known from the late Miocene of Ukraine (Falco medius Umans'ka, 1981), the Miocene of the USA (Falco ramenta Wetmore, 1936), and the Miocene of Argentina (Badiostes patagonicus Ameghino, 1895 and Thegornis musculosus Ameghino, 1895).

Members of the extinct Teratornithidae family were birds of prey of enormous sizes. Their wingspan may have reached 7-7.5 meters, with a weight of about 70 kilograms. Their earlies known species is the Argentavis magnificans (Campbell and Tonni, 1980) from the Miocene of Argentina, which may have been the largest as well. Species of the eponymous Teratornis genus (T. merriami Miller and Loye, 1909; T. incredibilis (Howard, 1952); T. woodburnensis (Campbell and Allison, 2002)) are known from the Pleistocene of the USA (Brodkorb 1964, Olson 1985, Bochenski 1997, Mlíkovský 2002).

\section{Systematics}

Finds of the fossil and subfossil diurnal predators of the Carpathian Basin are the following:

Abbreviations: MN 13 (6.8-5.3 MY) - Upper Miocene; MN 15 (4.5-3.2MY) - Middle Pliocene; MN 16-17 (3.2-1.8MY) MY) - Upper Pliocene; Q1-Q2(1.8-0.5 MY) - Lower Pleistocene; Q3 (Q3/I-Q3/II, 500.000-120.000 Y) - Middle Pleistocene; Q4/I (120.000 - 12.000Y) - Upper Pleistocene; Q4/II (12.000 Y - recent age) - $\uparrow$ - extinct/fossil species or subspecies.

\section{Ord. Accipitriformes (Vieillot, 1816) \\ Fam. Accipitridae (Vieillot, 1816)}

Vultures are typical scavengers of open areas (rocky cliffs and plains). Apart from the relatively small Egyptian Vulture (Neophron percnopterus), they are quite large, hence they do 
not really have any natural enemies. Their skeletal remains thus come from deaths of natural causes. They typically remained in crevices of rocks and caves they used for nesting and as feeding/resting places.

\section{- Aegypius Savigny, 1809}

- Aegypius monachus (Linnaeus, 1766)

Known from the Carpathian Basin Q3/I: Hundsheim (Austria) (Mlikovskỳ 1998, 2002); Q4/I: Cserépfalu - Subalyuk Cave (Hungary) (Jánossy 1962a, 1977); Nándori Cave (Nandru, Romania) (Jánossy 1965, Fischer \& Stephan 1977, Kessler 1985, Jurcsák \& Kessler 1988, Gál 2002a, 2003); Q4/II: Teufelslucken (Austria) (Soergel 1966); Balatonlelle hemp fields (Gál 2005); Visegrád Castle (Hungary) (Bökönyi \& Jánossy 1965, Jánossy 1977). Finds from Europe outside the Carpathian Basin: Q1-2: Spain; Q3: France; Q4: Bulgaria, Croatia, France, Georgia, Germany, Greece, Italy, Russia, Spain (Tyrberg 1998).

- Gyps Savigny, 1809

- Gyps † melitensis Lydekker, 1890

Known from the middle Pleistocene of Austria (Hundsheim (Jánossy 1974) and Repolusthöhle (Jánossy 1989) (Q3/II) and Hungary (Vértesszőlős 2 (Q3/I)). The extinct species was identified according to its dimensions.

Apart from the typical site (Zebbug Cave, Malta) it is also known from the site of Ta Kandija in Malta, Corsica, Crete, Mosbach (Germany), late Pleistocene sites of France (Soulabé and Harrpons), as well as from Monaco (Tyrberg 1998).

\section{- Gyps fulvus (Hablizl, 1873)}

Known from the Carpathian Basin Q3/I: Hundsheim (Austria) (Mlikovskỳ 1998, 2002); Q4/I: Krapina (Croatia) (Lambrecht 1915, V. Malez 1973, 1984); Varbó - Lambrecht Kálmán Cave (Hungary) (Jánossy 1977, 1986); Oláhszászka - Néravölgyi Cave (Sasca Româna - Valea Nerei) (Jurcsák \& Kessler 1988); Torda Gorge - Binder Cave (Turda, Romania) (Jurcsák \& Kessler 1988), Q4/II: Dunaújváros - Intrecisa (Jánossy 1985); Pilismarót-Malompatak (Hungary) (Jánossy 1985); Kőrösgyéres (Giriṣul de Criṣ) (Jurcsák \& Kessler 1986); Peterd - Torda Gorge-Magyar Cave (Petrești - Turda Romania) (Kessler \& Gál 1998, Gál 2004); Vársonkolyos - Kismagyar Cave (Suncuiuṣ - Peștera Napișteleu, Romania) (Jurcsák 1974, Kessler 1977, Gál 2002a). Finds from Europe outside the Carpathian Basin: Q3: Azerbaijan; Q4: Croatia, France, Georgia, Greece, Italy, Romania, Spain (Tyrberg 1998);

\section{- Gypaetus Storr, 1784}

\section{- Gyapaetus barbatus Linnaeus, 1758}

Known from the Carpathian Basin Q4/I: Cserépfalu - Subalyuk Cave (Jánossy 1960, 1962a, 1977, 1986); Hámor - Szeleta Cave (Lambrecht 1915, 1933); Ölyveskőér (Hungary) (Jánossy 1960); Ohábaponor - Bordu Mare Cave (Ohaba Ponor, Romania) (Kessler 1985, Jurcsák \& Kessler 1988, Gál 2002a, 2003); Q4/II: Kazánszoros - Töröklik Cave (Cazanele Mari - Cuina Turcului, Romania) (Kessler 1974c, Fischer \& Stephan 1977); Padina as Gypaetus/Aegypius/Gyps sp (Serbia) (Classon 1980, Gál 2004). Finds from Europe outside the Carpathian Basin: Q3: France; Q4: Belgium, France, Georgia, Greece, Italy, Spain (Tyrberg 1998);

\section{- $\uparrow$ Gypaetus asiaticus (Burchak-Abramovich, 1971)}


An extinct species reported from the Middle Pleistocene of Georgia (Tyrberg, 1998).

- Neophron percnopterus (Linnaeus, 1758)

Finds from Europe outside the Carpathian Basin: Q3: Azerbaijan; Q4: Bulgaria, Croatia, France, Greece, Spain (Tyrberg 1998);

- Circus (Lacépéde, 1799)

- Circus macrourus (Gmelin, 1771)

Known from the Carpathian Basin Q4/I: Pilisszántó I. Shelter Cave (Hungary) (Lambrecht 1915, 1933, Jánossy 1977, 1986); Nándori Cave (Nandru, Romania) (Jánossy 1965, Fischer \& Stephan 1977, Kessler 1985, Jurcsák \& Kessler 1988, Gál 2002a, 2003). Finds from Europe outside the Carpathian Basin: Q3: Azerbaijan, France; Q4: Czech Republic, France, Italy, Russia (Tyrberg 1998);

\section{- Circus cyaneus (Linnaeus, 1758)}

Known from the Carpathian Basin Q2: Osztramos 2 (Jánossy 1972, 1977, 1986); Q4/I: Bajót - Jankovich Cave (Lambrecht 1933, Jánossy 1977, 1986); Budapest - Remetehegy Shelter Cave (Kormos 1914; Lambrecht 1933, Jánossy 1977, 1986); Hámor - Puskaporos (Lambrecht 1912a, 1916, 1933, Jánossy 1977, 1986); Pilisszántó I - Shelter Cave (Hungary) (Lambrecht 1915, 1933, Jánossy 1977, 1986); Detrekőszentmiklós - Pálffy Cave (Dzeráva Skála - Plavecky Mikulas, Slovakia) (Lambrecht 1913, 1933). Finds from Europe outside the Carpathian Basin: Q3: Azerbaijan, France; Q4: Austria, Croatia, Czech Republic, France, Italy, Russia, Spain, Ukraine (Tyrberg 1998);

\section{- Circus aeruginosus (Linnaeus, 1758)}

Known from the Carpathian Basin Q3/II: Vindija (Croatia) (M. Malez 1961, V. Malez 1973, 1988, 1991, M. Malez \& Rukavina 1979); Q4/II: Röszke - Ludvár (Jánossy 1985, Gál 2004, 2007b); Tác-Gorsium (Hungary) (Bökönyi 1984, Jánossy 1985). Finds from Europe outside the Carpathian Basin: Q3: Azerbaijan; Q4: Bulgaria, Croatia, Czech Republic, Georgia, Germany, Italy, Netherlands, Russia (Tyrberg 1998);

- Circus pygargus (Linnaeus, 1758)

Finds from Europe outside the Carpathian Basin: Q3: France; Q4: Czech Republic, Italy, Ukraine (Tyrberg 1998);

\section{- Circus sp.}

Known from the Carpathian Basin Q1: Osztramos 2 (Hungary) (Jánossy 1972, 1986); Betfia 2 (Romania) (Kormos 1913, Čapek 1917, Lambrecht 1933, Jánossy 1977, 1986, Kessler 1975, Gál 2002a); Q4/II: Ecsegfalva 23. (Hungary) (Pike-Tay et al. 2004, Gál 2007b); Révi Caves (Peșteri din Vadu Crișului) (Kessler 1977b, 1982); Révtízfalusi Cave (Peștera din Zece Hotare, Romania) (Kessler 1985). Finds from Europe outside the Carpathian Basin: Q4: France, Spain (Tyrberg 1998);

- Circaetus (Viellot, 1816)

- Circaetus gallicus (Gmelin, 1788)

Known from the Carpathian Basin Q4/II: Röszke - Ludvár (Hungary) (Jánossy 1985, Gál 2004, 2007b). Finds from Europe outside the Carpathian Basin: Q4: France, Italy, Spain (Tyrberg 1998);

- Accipiter (Brisson, 1760)

- Accipiter gentilis (Linnaeus, 1758) 
Known from the Carpathian Basin Q3/I: Betfia 7/4 (Romania) (Kessler 1975, Jánossy 1977, Gál 2002a; Q3/II: Vindija (Croatia) (M. Malez 1961, V. Malez 1973, 1988, 1991, M. Malez \& Rukavina 1979); Q4/I: Budapest - Remetehegy Shelter Cave (Lambrecht 1933, Jánossy 1977, 1986); Varbó - Lambrecht Kálmán Cave (Hungary) (Jánossy 1977, 1986); Q4/II: Bajcsa (Gál 2002b); Dunaújváros - Intrecisa (Jánossy 1985); Ecsegfalva 23. (PikeTay et al., 2004, Gál 2007a, 2007b); Mezőzombor cemetery (Jánossy 1985, Gál 2007b); Tác-Gorsium (Bökönyi 1984, Jánossy 1985); Tác - Fövény-puszta (Hungary) (Jánossy 1977); Berettyószéplak (Suplacu de Barcău) (Jurcsák \& Kessler 1986, Gál, 2004); Körösbánlaki Cave (Peștera din Bălnaca) (Kessler 1982); Püspökfürdő Lake (Lacul din Băile 1 Mai) (Kessler 1974b, 1985); Révi Caves (Peșteri din Vadu Criṣului) (Kessler 1977, 1982); Szegyestel - Drăcoaia Cave, Caves in the Szegyestel valley (Peștera Drăcoaia, Peșteri din Valea Sighiștelului, Romania) (Kessler 1982). Finds from Europe outside the Carpathian Basin: Q3: Azerbaijan; Q4: Croatia, Czech Republic, France, Italy, Turkey (Tyrberg 1998);

- Accipiter gentilis † brachydactylus (Mourer-Chauviré, 1975)

Extinct subspecies. Finds from Europe outside the Carpathian Basin: Q3: France (Tyrberg 1998);

\section{- Accipiter nisus (Linnaeus, 1758)}

Known from the Carpathian Basin Q1: Beremend 17 (Hungary) (Jánossy 1987, Kessler 2009); Betfia 9 (Gál 2002a); Q3/I: Hundsheim (Austria) (Mlikovskỳ 2009); Q3/II: Tarkő (Hungary) (Jánossy 1962b, 1976, 1977, 1986); Q4/I: Budapest - Remetehegy Shelter Cave (Hungary) (Kormos 1914, Lambrecht 1933, Jánossy 1977, 1986); Q4/II: Bajcsa (Gál 2002b); Jósvafö - Musztáng Cave (Kessler 2009); Legény Cave (Hungary) (Lambrecht 1933); Esküllö - Kis Cave (Aștileu - Peștera Mica) (Kessler 1985); Kazánszoros - Töröklik Cave (Cazanele Mari - Cuina Turcului, Romania) (Kessler 1974c, Fischer \& Stephan 1977). Finds from Europe outside the Carpathian Basin: Q3: Czech Republic, France, Italy, Spain; Q4: Austria, Bulgaria, Croatia, Czech Republic, France, Georgia, Germany, Grece, Italy, Spain, Ukraine, United Kingdom (Tyrberg 1998);

\section{- Accipiter sp.}

Finds from Europe outside the Carpathian Basin: Q4: Germany, Portugal, Russia, Spain (Tyrberg 1998);

\section{- Milvus Lacépéde, 1799}

\section{- † Milvus brachypterus (Jánossy, 1977)}

Described from the early Pleistocene of Nagyharsány Hill 1-4. (Bihar level, Q1) (Jánossy 1977). The skeletal remain indicates a type with shorter, but more stout wing structure than that of the recent kite species according to Jánossy. Its morphological characteristics also match its genus.

Known only from the typical sites, still described by Lambrecht (1916) as "Archibuteo lagopus".

\section{- Milvus migrans (Boddaeert, 1783)}

Q4/II: Vlassac (Serbia) (Jánossy 1977);

Finds from Europe outside the Carpathian Basin: Q3: France; Q4: Czech Republic, France, Italy (Tyrberg 1998); 
Finds from Europe outside the Carpathian Basin: Q4: France, Italy, Spain, United Kingdom (Tyrberg 1998);

\section{- Milvus sp.}

Q4/II: Starcevo (Serbia) (Classon 1980, Gál 2004);

Finds from Europe outside the Carpathian Basin: Q3: Azerbaijan (Tyrberg 1998);

- Pernis (Cuvier, 1817)

- Pernis apivorus (Linnaeus, 1758)

Known from the Carpathian Basin Q4/I: Varbó - Lambrecht Kálmán Cave (Hungary) (Jánossy 1964, 1977); Nándori Cave (Curata Nandru, Romania) (Jánossy 1965, Fischer \& Stephan 1977, Kessler 1985, Jurcsák \& Kessler 1988, Gál 2002a, 2003). Finds from Europe outside the Carpathian Basin: Q3: Czech Republic; Q4: Germany (Tyrberg 1998);

- Buteo (Lacepede, 1799)

\section{- Buteo buteo (Linnaeus, 1758)}

Known from the Carpathian Basin Q1: Betfia 2 (Romania) (Kormos 1913, Čapek 1917, Lambrecht 1933, Jánossy 1977, Kessler 1975, Gál 2002a); Q3: Vindija (Croatia) (M. Malez 1961, V. Malez 1973, 1988, 1991); Q4/I: Cserépfalu - Subalyuk Cave (Jánossy 1960, 1962a, 1977, 1986); Diósgyör - Tapolca Cave (Jánossy 1977, 1978, 1986); Varbó - Lambrecht Kálmán Cave (Hungary) (Jánossy 1964, 1977, 1986); Q4/II: Budapest - Gellért Hill (Jánossy 1977); Ecsegfalva (Pike-Tay et al. 2004, Gál 2007a, 2007b); Gyula Castle (Hungary) (Jánossy 1977, 1985); Révi Caves (Peșteri din Vadu Crișului, Romania) (Kessler 1982). Finds from Europe outside the Carpathian Basin: Q1-2: Ukraine; Q3: France, Georgia, Turkey; Q4: Croatia, France, Georgia, Germany, Greece, Italy, Luxemburg, Poland, Portugal, Spain, United Kingdom (Tyrberg 1998);

\section{- Buteo lagopus (Pontoppidan, 1763)}

Known from the Carpathian Basin Q1: Nagyharsány Hill (Hungary) (Lambrecht 1916); Q2: Nagyharsány Hill 1-4 (Hungary) (Jánossy 1977, 1986); Q4/I: Budapest - Remetehegy Shelter Cave (Kormos 1914, Lambrecht 1933, Jánossy 1977, 1986); Kesztölc - Bivak Cave (Hungary) (Jánossy 1977, 1986); Nándori Cave (Curata Nandru, Romania) (Jánossy 1965, Fischer \& Stephan 1977, Kessler 1985, Jurcsák \& Kessler 1988, Gál 2002a, 2003); Detrekőszentmiklós - Pálffy Cave (Dzeráva Skála-Plavecky Mikulas, Slovakia) (Lambrecht 1913, 1933, Mottl 1938, 1941); Q4/II: Caves of Vársonkolyos (Peșteri din Şuncuiuṣ, Romania) (Kessler 1982). Finds from Europe outside the Carpathian Basin: Q4: Czech Republic, France, Germany, Italy, Moldova, Ukrajne, United Kingdom (Tyrberg 1998);

\section{- Buteo rufinus (Cretzschmar, 1827)}

Known from the Carpathian Basin Q4/I: Pilisszántó I. - Shelter Cave (Hungary) (Lambrecht 1915, 1933, Jánossy 1986). Finds from Europe outside the Carpathian Basin: Q3: Azerbaijan, France; Q4: France, Luxemburg, Spain (Tyrberg 1998);

\section{- Buteo sp. foss. indet.}

Known from the Carpathian Basin MN 13: Polgárdi 4 (Hungary) (Jánossy 1995, Kessler 2009);

- Buteo sp. indet.

Known from the Carpathian Basin Q3/I: Vindija (Croatia) (M. Malez 1961, V. Malez 1973, 1988, 1991). Finds from Europe outside the Carpathian Basin: Q1-2: Spain; Q3: 
Russia; Q4: Croatia, France, Germany, Poland, Russia (Tyrberg 1998);

- Aquila (Brisson, 1760)

- Aquila chrysaetus (Linnaeus, 1758)

Known from the Carpathian Basin MN 16: Villány 3 (Hungary) (Jánossy 1977, 1983, 1986); Q4/I: Krapina (Lambrecht 1915, V. Malez 1973, 1984, 1988); Veternica (Croatia) (V. Malez 1973, 1988); Cserépfalu - Subalyuk Cave (Jánossy 1960, 1962a, 1977, 1986); Pilisszántó (Lambrecht 1915, 1933, Jánossy 1977, 1986); Mérk (Hungary) (Lambrecht 1912); Körösmart (Râpa, Romania) (Jánossy in Hamar \& Csák 1969, Kessler 1974a, Gál 2002a); Q4/II: Dunaújváros - Intrecisa (Jánossy 1985); Csákvár - Esterházy Cave (Kretzoi 1954); Mezőfény (Gál 2004); Tápiószele - Tüzköves (Jánossy 1977); Tiszalúc-Sarkad (Jánossy 1985, Gál 2007b); Visegrád Castle (Hungary) (Gál 2005); Kazánszoros-Töröklik (Cazanele Mari - Cuina Turcului, Romania) (Kessler 1974c, Fischer \& Stephan 1977). Finds from Europe outside the Carpathian Basin: Q3: Azerbaijan, Czech Republic, France, Georgia, Italy; Q4: Austria, Croatia, Czech Republic, France, Georgia, Germany, Greece, Italy, Moldova, Spain, Ukraine, United Kingdom (Tyrberg 1998);

- Aquila heliaca (Savigny, 1809)

Known from the Carpathian Basin Q2: Somssich Hill 2 (Hungary) (Jánossy 1983, 1986); Q3/I: Hundsheim (Austria) (Jánossy 1974, 1977); Betfia 7/4 (Romania) (Kessler 1975, Jánossy 1977, Gál 2002a); Q4/I: Varbó - Lambrecht Kálmán Cave (Hungary) (Jánossy 1964, 1977); Q4/II: Teufelslucken (Austria) (Soergel 1966); Vlassac (Serbia) (Jánossy 1977). Finds from Europe outside the Carpathian Basin: Q3: Azerbaijan; Q4: Austria, Georgia, Italy, Switzerland (Tyrberg 1998);

- Aquila clanga (Pallas, 1811)

Known from the Carpathian Basin Q1: Betfia 9 (Romania) (Kessler 1985, Gál 2002a); Q4/I: Nándori Cave (Curata Nandru, Romania) (Jánossy 1965, Fischer \& Stephan 1977, Kessler 1985, Jurcsák \& Kessler 1988, Gál 2002a, 2003). Finds from Europe outside the Carpathian Basin: Q3: Azerbaijan, France; Q4: France, Germany, Italy (Tyrberg 1998);

\section{- Aquila clanga/pomarina}

Known from the Carpathian Basin Q4/II: Ludas-Budzsák (Hungary) (Bökönyi 1984, Gál 2004);

- Aquila pomarina (C.L.Brehm, 1831)

Known from the Carpathian Basin Q4/II: Tiszaszölös - Gomaháza-Puszta (Hungary) (Gál 2007b). Finds from Europe outside the Carpathian Basin: Q3: Azerbaijan; Q4: Bulgaria, Romania (Tyrberg 1998);

- Aquila rapax (Cabanis, 1854)

Known from the Carpathian Basin Q4/II: Bajcsa - Castle (Hungary) (Gál 2002b). Finds from Europe outside the Carpathian Basin: Q3: Azerbaijan, Czech Republic; Q4: Germany, Moldova (Tyrberg 1998);

\section{- Aquila adalberti (Brehm, 1861)}

Finds from Europe outside the Carpathian Basin: Q4: Spain (Tyrberg 1998);

- $\uparrow$ Aquila chrysaetos bonifacti (Mourer-Chauviré, 1975)

Finds from Europe outside the Carpathian Basin: Q3: France (Tyrberg 1998);

$-\uparrow$ Aquila chrysaetos simurg (Weeseie, 1987) 
Extinct subspecies. Finds from Europe outside the Carpathian Basin: Q4: Greece (Tyrberg 1998);

\section{- Aquila sp.}

Known from the Carpathian Basin Q3/I: Hundsheim (Austria) (Mlikovskỳ 2009); Q4/ II: Starcevo (Serbia) (Classon 1980, Gál 2004). Finds from Europe outside the Carpathian Basin: Q1-2: Bulgaria; Q3: Italy, Ukraine; Q4: Austria, Belgium, Czech Republic, France, Georgia, Germany, Italy, Russia, Spain, United Kingdom (Tyrberg 1998);

- Haliaeetus (Savigny, 1809)

- $\uparrow$ Haliaeetus aff. angustipes (Jánossy, 1983)

A metacarpus (III.) was described based on a fragment from the Lower Pleistocene of Betfia 5 (Jánossy 1983, Gál 2002a).

The only defining characteristic is the slimness of the fossilized tarsometatarsus compared to the recent specimens, which can be shown on the fossil found on the typical site in the Czech Republic. Based on finds from the early Pleistocene Betfia and Bugiuleşt (Romania, the southern slope of the Carpathian Basin), Erika Gál (Gál 2002a) described the same characteristic, which we experienced firsthand. Gracility also meant an adaptation to the environment, which can also be seen for example on the typically narrow tarsometatarsus of harriers. The two types of predators may have lived in similar environments and may have nested in reed beds and underbushes during the Pliocene and the lower Pleistocene. The recent white-tailed eagles, however, live in floodplain forests and nests on trees. This may explain the size difference of the skeletal remains of their legs. Erika Gál describes it from the early Pleistocene finds of Bugiuleşti (Romania) (Gál 2002a), while Mlikovskỳ $(1998,2002)$ describes it as belonging to the recent species.

\section{- Haliaeetus albicilla (Linnaeus, 1758)}

Known from the Carpathian Basin Q4/I: Krapina (Croatia) (Lambrecht 1915, V. Malez 1973, 1984, 1988); Esküllő - Igric Cave (Aștileu-Peștera Igriţa) (Kormos 1914, 1916); Nándori Cave (Curata Nandru) (Jánossy 1965, Fischer \& Stephan 1977, Kessler 1985, Jurcsák \& Kessler 1988, Gál 2002a, 2003); Ohábaponor (Peștera Ohaba Ponor, Romania) (Kessler 1985, Jurcsák \& Kessler 1988, Gál 2002a, 2003); Q4/II: Balatonlele hemp fields (Gál 2005); Berettyószentmárton (Jánossy 1977, 1985, Gál 2007a, 2007b); Dunaújváros-Intrecisa (Jánossy 1985); Gyula - Castle (Jánossy 1977, 1985); Kisköre-Szingegát (Jánossy 1985, Gál 2004, 2007a, 2007b); Ludas - Budzsák (Bökönyi 1984, Gál 2004); Röszke - Ludvár, Szegvár - Tüzköves, Szerencs - Taktaföldvár, Szolnok - Szanda (Jánossy 1985, Gál 2004, 2007a, 2007b); Tác - Gorsium (Bökönyi 1984, Jánossy 1985); Tiszalök - Rázom (Jánossy 1977); Tiszalúc - Sarkad (Hungary) (Jánossy 1985, Gál 2007a, 2007b); Peterd - Torda Gorge-Magyar Cave (Petrești - Turda, Peștera Ungurească, Romania) (Kessler \& Gál 1998, Gál 2004); Padina (Classon 1980, Gál 2004); Vlassac (Serbia) (Jánossy 1977). Finds from Europe outside the Carpathian Basin: Q1.2: Netherlands; Q3: Azerbaijan, Czech Republic, France, Germany, Greece, Italy; Q4: Austria, Croatia, Czech Republic, France, Georgia, Germany, Greece, Italy, Poland, Russia, Spain, United Kingdom (Tyrberg 1998);

\section{- ?Haliaeetus sp. foss. indet.}

Known from the Carpathian Basin MN 1-4: Erösd (Lambrecht 1929). 
(Note: the Lambrecht paper quoted in the literature numerous times does not contain the description from Erösd. There is no such material either in the collection of NHMUS (Natural History Museum of Hungary) or GGIH (Geological and Geophysical Institute of Hungary))

- Hieraetus (Kaup, 1844)

- Hieraetus pennatus (Gmelin, 1788)

Known from the Carpathian Basin Q4/II: Ecsegfalva (Hungary) (Pike-Tay et al. 2004, Gál 2007a, 2007b). Finds from Europe outside the Carpathian Basin: Q3: Azerbaijan; Q4: Spain, Russia, United Kingdom (Tyrberg 1998);

- Hieraetus fasciatus (Viellot, 1822)

Finds from Europe outside the Carpathian Basin: Q3: France; Q4: Italy, Malta, Spain (Tyrberg 1998);

- Buthierax pouliani (Kretzoi, 1977)

Finds from Europe outside the Carpathian Basin: Q3: Greece (Tyrberg 1998).

Fam. Pandionidae Savigny, 1809

- Pandion Savigny, 1809

- Pandion pannonicus sp. $\mathbf{n}$.

Holotype - material: distal phalanx (phalanx 3., digiti II.)

Site and age: Máriahalom (Hungary), Upper Oligocene (MP 25). „The village of Máriahalom is located in the northeastern boarder of the Mány-Zsámbék basin, $47 \mathrm{~km}$ north-west from Budapest. The sand pit is situated on the south-western side of the road between the townships of Úny and Máriahalom." (Rabi \& Botfalvi 2008). The fossil remains - collected among other by Zoltán Evanics - contains fish, reptiles, birds and mamals. The fossil material of birds is very fragmented, containing elements from the aquatic environment. This material is in the collection of the Department of Paleontology at Eötvös Loránd University, Budapest, Hungary.

Diagnosis: Smaller than fossil and recent known osprey species, but it should be a much earlier species described according to a typical osprey skeletal part. The tuberculum extensorium (a) is oblique with a blunt end; the cotyla articularis (b) has an assymmetrical curve; the neck of the tuberculum flexorium (c) is short, the lower part is convex in the middle; the corpus phalangis (d) is wide and curved; (the apex phalangis is damaged) (Figure 1.1).

Etymology: After the name of Pannonia province.

Dimensions: Total measurable length is $A=20.50 \mathrm{~mm}$ (it might have been $22-24 \mathrm{~mm}$ ), length of the joint surface (from the tub. extens. to the end of the tub. flex.) $B=9.76 \mathrm{~mm}$, the middle width of the tuberculum flexorium is $(\mathrm{C})=3.51 \mathrm{~mm}$; the biggest width of the $t u$ berculum flexorium is $(\mathrm{D})=5.23 \mathrm{~mm}$, the biggest width of the claw shaft is $(\mathrm{E})=4.94 \mathrm{~mm}$. (Figure 1.2).

Comparative material: Pandion haliaetus recent ph.3.dig.II. distal phalanges (NHMUS $\mathrm{n}=4$, male and female: C.58.11.1; 69.9.17; 791000; 830.621 = A: 23.92-27.13 mm; B: 9.64-12.12 mm; D=5.17-5.83 mm) and ph.2.dig.I.; ph.4.dig.III.; ph.5.dig.IV.distal phalanges (Figure 1.5).

Abrevations: NHMUS - Natural History Museum of Hungary, Budapest.

Method: For the discussed skeletal part, the anatomical terminology (after: Lambrecht 1933, Baumel et al. 1979, Solti 1996, Kessler 2013a) and method of measurement (Solti 
1996, Kessler 2013) of the bone in question is given, illustrated by the appropriate bone of the fossil specimens and recent species.

Description: The typical osprey claw, the tuberculum flexiorum major (all of its skeletal parts differ from other diurnal predators!), can easily be identified due to its elongated form. The shape of the end of the projection decides which finger the claw may have belonged to (on the first finger it is asymmetrical, on the second it is flattened and protuberant in the middle, on the third it is semi-circularly protruberand, on the fourth it is cone shaped, see Plate, Figure 4-7. The issue is caused by the difference of the bottom part of the fossil's tuberculum flexorium compared to both the four claws of the recent species, as well as in the case of known fossilized claws which partially come from different fingers and earlier layers.

Discussion: The two known fossil species are either larger than the recent species, or match it in size. The first fossilized species was described by S. L. Warter (1976) from the middle Miocene (14.5-13 million years) layers of Sharkstooth Hill, California (USA), with the name Pandion homalopteron Warter, 1976 (Warter 1976), based on the humerus and ulna. The size is similar to that of the recent species, or slightly bigger.

The second known fossil species was also reported from North America by Becker (1985) from the upper Miocene river sediments of Love Bone Bed, Florida (9 million years) (Alachua Formation). The find consists of a distal femur, a complete and a distal tibiotarsus, a complete and a somewhat partial tarsometatarsus and 3 claws, and is named Pandion lovensis Becker, 1985 (Becker 1985). Sadly, only one of the claws (Ph 2. dig. I.) is presented as picture (https://www.floridamuseum.ufl.edu/florida-vertebrate-fossils/species/pandion-lovensis/) (Figure 1.8), with no description available. We did not receive the requested information of the other two, thus they cannot serve as basis for comparison. The dimensions of the other three skeletal parts, however, confirm that the sizes match those of the recent Pandion haliaetus.

The third find is known from the early Pliocene (Yorktown Formation) of Lee Crek Mine (North Carolina, USA) (Olson \& Rassmusen 2001). They also reported a claw (p. 298) of which they only gave the $\mathrm{B}$ and $\mathrm{D}$ dimensions $(\mathrm{B}=12.6 \mathrm{~mm} ; \mathrm{D}=5 \mathrm{~mm}$ ) and identified it as Pandion sp. The tuberculum flexorium differs from that of the find from Máriahalom, and according to its characteristics, it is a phalanx 5. digiti IV (Figure 1.9). Also from Florida, but the middle Pliocene (Bone Valley Formation) comes another Pandion claw, which is mentioned without details (Brodkorb 1972).

The earlist find (Olson 1985, Rasmussen et al. 1987) comes from the lower Oligocene of Fayum, Egypt (Jebel Quatrami Formation); from there the distal epiphisys of a humerus (width $\mathrm{F}=16.9 \mathrm{~mm}$, in case of the recent species 22-24.8 mm) and a damaged carpometatarsus was described (its length was $A=83 \mathrm{~mm}$, in case of the recent species $80-87.5 \mathrm{~mm}$ ), reported as Pandionidae, gen et species indet.

The dimensions of the two fossil species match those of the recent subspecies found in America and Europe (including sexual dimorphism), but the tarsometatarsus of the fossilized species from Florida is longer and its trochlea more robust than those of recent representatives (see Table 1 with measurements). This, of course indicates that the phalanges connected to them must also be larger, so as the claws. The material from Máriahalom, however, is somewhat smaller than the appropriate recent claws. Since the morphological 


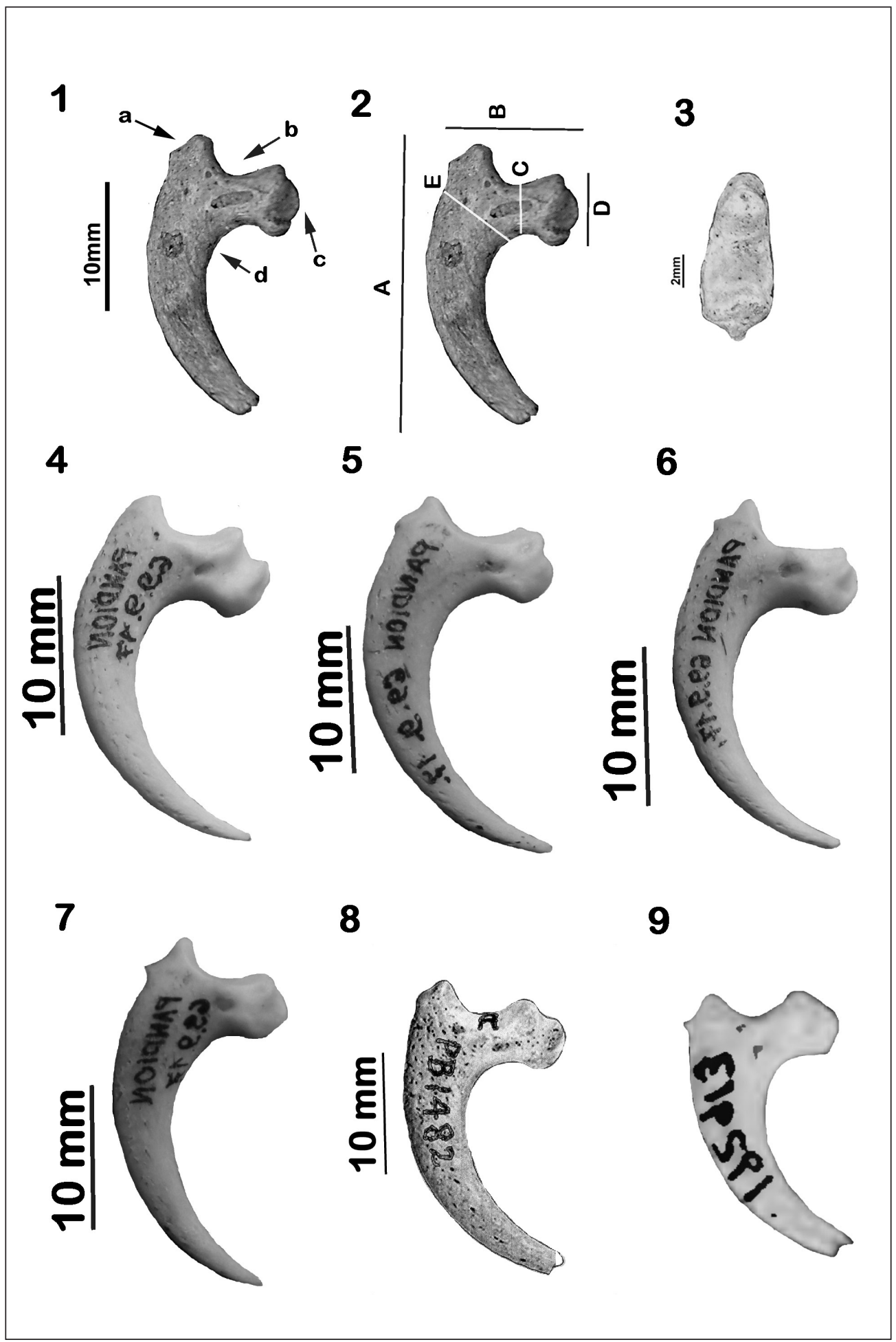


Figure 1.

1. Pandion pannonicus n. sp. Phalanx 3, Digiti Il. a - tuberculum extensorium; b-cotyla articularis;

$\mathrm{c}$ - tuberculum flexorium; $\mathrm{d}$ - corpus phalangis

2. Method of measurement: $A$ - total length; $B$ - length of the joint surface; $C$ - middle width of the tuberculum flexorium; D - biggest width of the tuberculum flexorium; $\mathrm{E}$ - biggest width of the claw shaft

3. Pandion pannonicus n. sp. proximal view of the claw

4. Pandion haliaetus rec. Phalanx 2, Digiti I.

5. Pandion haliaetus rec. Phalanx 3, Digiti II.

6. Pandion haliaetus rec. Phalanx 4, Digiti III.

7. Pandion haliaetus rec. Phalanx 5, Digiti IV.

8. Pandion lovensis Becker, 1985 foss. Phalanx 2, Digiti I.

9. Pandionidae sp. foss. from Lee Crek Mine, Phalanx 5, Digiti IV.

1. ábra

1. Pandion pannonicus n. sp. Phalanx 3, Digiti Il. a - tuberculum extensorium; b - cotyla articularis; $\mathrm{c}$ - tuberculum flexorium; $\mathrm{d}$ - corpus phalangis

2. A mérési modell: A - teljes hossz; B - ízesülési felület hossza; C - tuberculum flexorium közepének szélessége; D - tuberculum flexorium legnagyobb szélessége; $\mathrm{E}$ - karomcsont test legnagyobb szélessége

3. Pandion pannonicus $\mathrm{n}$. sp. karomcsont proximális nézetből

4. Pandion haliaetus rec. Phalanx 2, Digiti I.

5. Pandion haliaetus rec. Phalanx 3, Digiti II.

6. Pandion haliaetus rec. Phalanx 4, Digiti III.

7. Pandion haliaetus rec. Phalanx 5, Digiti IV.

8. Pandion lovensis Becker, 1985 foss. Phalanx 2, Digiti I.

9. Pandionidae sp. foss. from Lee Crek Mine, Phalanx 5, Digiti IV.

characteristics are impossible to mistake for the skeletal part of any other bird of prey, due to its age, it is evident that it can not be identical to the recent species. Also, since it is one of the oldest such finds in the world, it can be responsibly described as a new taxon, despite not being able to tell exactly which finger the claw belonged to!

Spread: ospreys are exceptionally rare around the world among fossilized finds (as a cosmopolitan species). The recent species is known from the Upper Pliocene of Villány (Villány 3) and a few finds from the Quaternary, for example the Upper Pleistocene sediments of the Cioraei Cave in Romania (Kessler \& Gál 2001, Kessler 2009). The latter was identified from a claw (phalanx 4. digiti III). It probably belongs to a male specimen.

Ospreys have typical lifestyles, feeding on fish. Thus, their presence indicates such an environment (large, open waters: rivers, lakes, seas). Currently, it is a rare species in the Carpathian Basin, as a migrant or summer vagrant. Its presence in the upper Oligocene also indicates a seashore environment.

\section{- Pandion haliaetus (Linnaeus, 1758)}

Known from the Carpathian Basin MN 16-17: Villány 3 (Hungary) (Kessler 2009). Finds from Europe outside the Carpathian Basin: Q3: Italy, United Kingdom; Q4: Georgia, Germany, Italy, Spain, Switzerland, Ukraine, United Kingdom (Tyrberg 1998); Romania (Gál \& Kessler 2001). 
Table 1. Osprey bones measurement

1. táblázat Halászsas csontok mérettáblázata

\begin{tabular}{|c|c|c|c|c|c|c|c|}
\hline 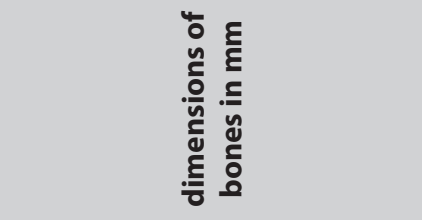 & 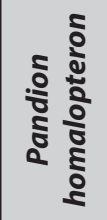 & 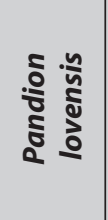 & 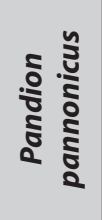 & $\begin{array}{l}\frac{2}{0} \\
\frac{0}{\delta} \\
\frac{\delta}{5} \\
\frac{\delta}{\delta} \\
\frac{\delta}{\delta} \\
2\end{array}$ & 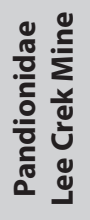 & 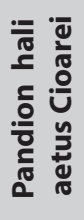 & 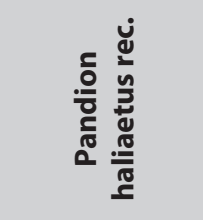 \\
\hline \multicolumn{8}{|l|}{ Humerus } \\
\hline A (total lenght) & 151.00 & & & & & & $135.00-154.00$ \\
\hline C (width of proximal epiphysis & 27.50 & & & & & & $25.00-28.50$ \\
\hline$E$ (width of shaft) & 12.00 & & & & & & $11.00-12.00$ \\
\hline F (width of distal epiphysis) & 24.50 & & & 16.90 & & & $22.00-24.80$ \\
\hline \multicolumn{8}{|l|}{ Ulna } \\
\hline A (total lenght) & 120.00 & & & & & & 166.00 \\
\hline \multicolumn{8}{|l|}{ Carpometacarpus } \\
\hline A (total lenght) & & & & 83.00 & & & $80.00-87.50$ \\
\hline \multicolumn{8}{|l|}{ Femur } \\
\hline E (thichness of diaphysis) & & 7.20 & & & & & $7.00-8.30$ \\
\hline F (thickness of distal epiphysis) & & 15.20 & & & & & $14.00-17.40$ \\
\hline G (width of dsital epiphysis) & & 12.80 & & & & & $12.70-14.20$ \\
\hline \multicolumn{8}{|l|}{ Tibiotarsus } \\
\hline A (total lenght) & & 124.80 & & & & & $115.00-130.80$ \\
\hline $\begin{array}{l}\text { C (thickness of proximal } \\
\text { epiphysis) }\end{array}$ & & 17.00 & & & & & $15.90-18.50$ \\
\hline D (width of proximal epiphysis) & & 13.10 & & & & & $12.30-14.20$ \\
\hline \multicolumn{8}{|l|}{ Tarsometatarsus } \\
\hline A (total lenght) & & 59.50 & & & & & $49.00-54.90$ \\
\hline F (thickness of distal epiphysis) & & 16.40 & & & & & $14.00-15.90$ \\
\hline \multicolumn{8}{|l|}{ Phalanx 2. Digiti I. } \\
\hline A (total lenght) & & $\begin{array}{l}\text { cca. } \\
27.0\end{array}$ & & & & & $24.04-27.77$ \\
\hline B (thickness of proximal end) & & $\begin{array}{l}\text { cca. } \\
12.0\end{array}$ & & & & & $10.81-11.85$ \\
\hline C (middle width of tub.flexor.) & & $\begin{array}{l}\text { cca. } \\
4.6\end{array}$ & & & & & $4.51-4.90$ \\
\hline D (biggest width of tub. flexor.) & & $\begin{array}{l}\text { cca. } \\
5.5\end{array}$ & & & & & $5.23-5.79$ \\
\hline E (biggest width of the corpus) & & $\begin{array}{l}\text { cca. } \\
6.0\end{array}$ & & & & & $4.76-6.67$ \\
\hline \multicolumn{8}{|l|}{ Phalanx 3. Digiti II. } \\
\hline A (total lenght) & & & $\begin{array}{c}\text { cca. } \\
22-24\end{array}$ & & & & $23.92-27.13$ \\
\hline
\end{tabular}




\begin{tabular}{|c|c|c|c|c|c|c|c|}
\hline 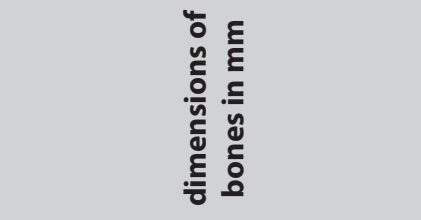 & 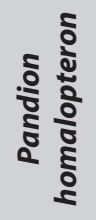 & 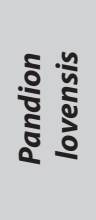 & 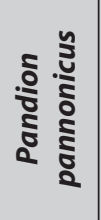 & 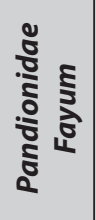 & 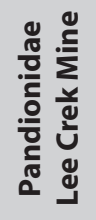 & 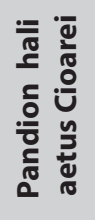 & 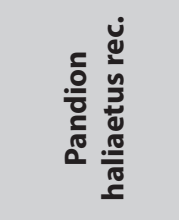 \\
\hline B (thickness of proximal end) & & & 9.76 & & & & $9.64-12.12$ \\
\hline C (middle width of tub.flexor.) & & & 3.51 & & & & $3.58-5.15$ \\
\hline D (biggest width of tub. flexor.) & & & 5.23 & & & & $5.17-5.83$ \\
\hline E (biggest width of the corpus) & & & 4.94 & & & & $5.06-5.42$ \\
\hline \multicolumn{8}{|l|}{ Phalanx 4. Digiti III. } \\
\hline A (total lenght) & & & & & & 35.40 & 24.13-26.78 \\
\hline B (thickness of proximal end) & & & & & & 11.20 & $10.26-12.23$ \\
\hline C (middle width of tub.flexor.) & & & & & & & $3.65-5.15$ \\
\hline D (biggest width of tub. flexor.) & & & & & & 5.10 & $4.76-5.79$ \\
\hline E (biggest width of the corpus) & & & & & & & $4.89-5.72$ \\
\hline \multicolumn{8}{|l|}{ Phalanx 5. Digiti IV. } \\
\hline A (total lenght) & & & & & & & $23.57-26.16$ \\
\hline B (thickness of proximal end) & & & & & 12.60 & & $9.99-11.12$ \\
\hline C (middle width of tub.flexor.) & & & & & & & $4.00-4.74$ \\
\hline D (biggest width of tub. flexor.) & & & & & 5.00 & & $4.83-5.27$ \\
\hline E (biggest width of the corpus) & & & & & & & $5.12-5.60$ \\
\hline
\end{tabular}

\section{Ord. Falconiformes (Leach, 1820)}

Fam. Falconidae (Vigors, 1824)

Falcons and kestrels are diurnal predators of open areas. They are especially swift flyers, also indicated by their physique and wings. Their preys fit their sizes, which indicates their environments, as do their mating habits. Their sexual dimorphism is indicated by their difference in size; the females are significantly larger than the males. Specimens capable of flight but not yet sexually mature (subadultus) are richly represented even in large groups among fossilized material (for example in cave 4 of Calvary Hill in Tatabánya). Falcons - especially before maturing - are wanderers, while kestrels mostly migrate.

\section{- Falco (Linnaeus, 1758)}

\section{- $\uparrow$ Falco aff. antiquus (Mourer-Chauviré, 1975)}

It was identified from the middle Pleistocene sediments of the Cserépfalu-Hórvölgy Cave (Hungary) (Jánossy 1977, 1986, Kessler 2009). Finds from Europe outside the Carpathian Basin: Q3: France (Tyrberg 1998). It belongs to bigger falcons and is a transition between the Saker Falcon and the Gyrfalcon. The fossilized species was described from the La Fage site in France (Q3) (Mourer-Chauviré 1975), but according to Mlikovskỳ (2002) there are no morphological differences when compared to the recent Saker Falcon (Falco cherrug). 


\section{- † Falco tinnunculus atavus (Jánossy, 1972)}

Known from the Carpathian Basin MN 13: Polgárdi 5 (Hungary) (Jánossy 1995, Kessler 2009); MN 15: Beremend 26 (Hungary) (Kessler 2009); Csarnóta 2 (Jánossy 1977, Kessler 2009); MN 16: Beremend 15 (Hungary) (Jánossy 1987, Kessler 2009); Q1: Németóvár (Deutsch-Altenburg, Austria) (Jánossy 1981); Beremend 16, 17 (Hungary) (Jánossy 1992); Betfia 2, 9, (Romania) (Jánossy 1977, Kessler 1975, Gál 2002a); Q2: Nagyharsány Hill 1-4, Somssich Hill 2 (Jánossy 1977, 1981, 1982, 1983, 1986); Villány 5 (Hungary) (Kessler 2009); Betfia 7, „Aven” (Kessler 1975, Jánossy 1977, Gál 2002a); Betfia 5, 7/2-3 (Romania) (Kessler 1975, Jánossy 1977, Gál 2002a); Méhész (4E) (Vcelare, Slovakia) (Jánossy 1977); Q3/I: Hundsheim (Austria) (Jánossy 1974, 1977); Tarkő 1-16 (Hungary) (Jánossy1977) Betfia 7/4 (Romania) (Kessler 1975, Jánossy 1977, Gál 2002a); Gombaszög (Gombasek, Slovakia) (Kessler 2009). Finds from Europe outside the Carpathian Basin: Q1-2: France; Q3: Czech Republic, France, Netherlands, Poland (Tyrberg 1998).

The diagnosis of fossil subspecies is based on the proportions of the dimensions, according to which it is more solid than the recent species. It has been reported from several lower and middle Pleistocene sites from all across Europe. Despite the fact that Mlikovskỳ (2002) classifies it as belonging to the recent species, in our opinion, the distinction of the fossil subspecies is justified due to the age of the finds and the size differences mentioned above.

\section{- Falco tinnunculus (Linnaeus, 1758)}

Known from the Carpathian Basin Q3/II: Cserépfalú - Hórvölgy Cave (Jánossy 1962a, 1977, 1986); Süttő 1-4 (Hungary) (Jánossy 1977, 1986); Q4/I: Merkestein (Austria) (Wettstein \& Mühlhofer 1938); Budapest - Remete Cave (Jánossy 1977, 1986); Budapest Remetehegy Cave (Kormos 1914, Lambrecht 1933, Jánossy 1977, 1986); Cserépfalu Subalyuk Cave (Jánossy 1962a, 1977, 1986); Csobánka - Kiskevély Cave (Jánossy1977); Érd (Jánossy 1977, 1986); Felsőtárkány - Peskő Cave (Lambrecht 1912, 1933, Jánossy 1977, 1986); Hámor - Puskaporos Shelter Cave (Lambrecht 1912, 1916, 1933, Jánossy 1977, 1986); Hámor - Herman Ottó Cave (Lambrecht 1915, 1933); Pilisszántó I. - Shelter cave (Lambrecht 1915, 1933, Jánossy 1977, 1986); Répáshuta - Balla Cave (Lambrecht 1912, 1933); Szilvásvárad-Istállóskő Cave (Lambrecht 1912, 1933, Jánossy 1952, 1977 , 1986); Tatabánya - Calvary Cave n. 4. (Gál 2004, 2005); Tatabánya - Szelim Cave (Jánossy 1977, 1986); Vaskapu Cave (Hungary) (Mottl 1941, Válóczi 1999); Hidegszamos - Csont Cave (Someșul Rece - Peștera cu Oase) (Lambrecht 1915); Körösmart (Râpa) (Jánossy in Hamar \& Csák 1969, Kessler 1974a, Gál 2002a); Nándori Cave (Curata-Nandru, Romania) (Jánossy 1965, Fischer \& Stephan 1977, Kessler 1985, Jurcsák \& Kessler 1988, Gál 2002a, 2003); Detrekőszentmiklós - Pálffy Cave (Dzeráva Skála-Plavecky Mikulas, Slovakia) (Lambrecht 1913, 1933); Q4/II: Teufelslucken (Soergel 1966); Tropfsteinhöhle (Austria) (Fladerer 1993). Felsőnyék - Várhegy (Gál 2007a); Felsőtárkány - Petényi Cave (Hungary) (Jánossy 1977, 1986); Herkulesfürdő - Rabló Cave (Băile Herculane - Peṣtera Hoţilor) (Kessler 1980-81, Gál 2002a); Remetelórév - Bólyikői Cave (Lorău-Peștera Piatra Boiului) (Kessler 1982); Révtizfalusi Cave (Peștera din Zece Hotare) (Kessler 1985); Szegyestel - Drăcoaia-Cave (Peștera Drăcoaia - Valea Sighiṣtelului) (Kessler 1982); Székelykeresztúr (Cristuru Săcuiesc, Romania) (Gál 2008); Finds from Europe outside the Carpathian Basin: Q1-2: Czech Republic, Greece; Q3: Azerbaijan, Czech Republic, France, 
Georgia, Italy, Spain, Ukraine; Q4: Austria, Belgium, Bosnia-Herzegovina, Croatia, Czech Republic, France, Georgia, Germany, Greece, Ireland, Italy, Moldova, Montenegro, Poland, Portugal, Russia, Spain, Switzerland, Ukraine, United Kingdom (Tyrberg 1998);

\section{- Falco vespertinus (Linnaeus, 1766)}

Known from the Carpathian Basin MN 16: Betfia 13 (Romania) (Kessler 1975, Gál 2002a); Q1: Betfia 2, 7, 9 (Romania) (Kormos 1913, Čapek 1917, Lambrecht 1933, Jánossy 1977, Kessler 1975, Gál 2002a); Q1-2: Betfia „Aven” (Romania) (Kessler 1975, Jánossy 1977, Gál 2002a); Q2: Somssich Hill 2 (Hungary) (Jánossy 1983); Q3/I: Hundsheim (Austria) (Mlikovskỳ 2009); Betfia 7/4 (Hungary) (Kessler 1975, Jánossy 1977, Gál 2002a); Q4/I: Budapest - Remetehegy Shelter Cave (Kormos 1914, Lambrecht 1933, Jánossy 1977, 1986); Cserépfalu - Subalyuk Cave (Jánossy 1962a, 1977, 1986); Hámor - Puskaporos Shelter Cave (Lambrecht 1912a, 1916, 1933, Jánossy 1977, 1986); Pilisszántó I. Shelter Cave (Lambrecht 1915, 1933, Jánossy 1977, 1986); Szilvásvárad-Istállóskői Cave (Hungary) (Lambrecht 1912b, 1933, Jánossy 1952, 1955, 1977, 1986); Ohábaponor - Bordu Mare Cave (Ohaba Ponor - Peștera Bordu Mare, Romania) (Kessler 1985, Jurcsák \& Kessler 1988, Gál 2002a, 2003). Finds from Europe outside the Carpathian Basin: Q3: Czech Republic, France; Q4: Bulgaria, France, Georgia, Germany Italy, Moldova, Spain, Ukraine (Tyrberg 1998);

\section{- Falco subbuteo (Linnaeus, 1758)}

Known from the Carpathian Basin Q1: Betfia 9 (Romania) (Kessler 1975, Gál 2002a); Q1-2: Betfia „Aven” (Romania) (Kessler 1975, Jánossy 1977, Gál 2002a); Q3/II: Vindija (Croatia) (M. Malez 1961, V. Malez 1973, 1988, 1991, Malez \& Rukavina 1979); Q4/I: Kesztölc-Bivak Cave (Jánossy 1977); Tatabánya - Szelim (Hungary) Cave (Jánossy 1977, 1986); Segyestel - Tibocoaia Cave (Valea Sighiștelului-Peștera Tibocoaia) (Kessler 1982, 1985, Gál 2002a); Detrekőszentmiklós - Pálffy Cave (Dzeráva Skála-Plavecky Mikulas, Slovakia) (Lambrecht 1913, 1933); Q4/II: Körösbánlaki Cave (Peștera din Bălnaca) (Kessler 1982); Peterd - Turda Gorge-Magyar Cave (Petrești - Turda, Peștera Ungureasca) (Kessler \& Gál 1998, Gál 2004); Révi Caves (Peșteri din Vadu Crișului) (Kessler 1982); Szegyestel - Drăcoaia Cave (Valea Sighiștelului, Peștera Drăcoaia, Romania) (Kessler 1982). Finds from Europe outside the Carpathian Basin: Q3: Czech Republic, France, Georgia, Germany, Italy; Q4: Austria, Croatia, France, Georgia, Germany, Greece, Italy, Spain, Ukraine, United Kingdom (Tyrberg 1998);

\section{- Falco cherrug (Gray, 1844)}

Known from the Carpathian Basin Q1: Betfia 9 (Hungary) (Kessler 1985, Gál 2002a); Q3/I; Betfia 7/4 (Hungary) (Kessler 1975, Jánossy 1977, Gál 2002a); Q4/I: Pilisszántó I. - Shelter Cave (Hungary) (Lambrecht 1915, 1933, Jánossy 1977, 1986); Q4/II: Remetelórév - Bólyikő Cave (Lorău - Peștera Piatra Boiului) (Kessler 1982); Szegyestel - Drăcoaia Cave (Valea Sighiștelului - Peștera Drăcoaia, Romania) (Kessler 1982). Finds from Europe outside the Carpathian Basin: Q3: Czech Republic; Q4: Croatia, Slovenia, Ukraine (Tyrberg 1998);

\section{- Falco peregrinus (Tunstall, 1771)}

Known from the Carpathian Basin Q4/I: Bajót - Hóman Cave (Jánossy 1977, 1986); Bajót - Jankovich Cave (Lambrecht 1933, Jánossy 1977, 1986); Cserépfalu - Subalyuk 
(Jánossy 1962a, 1977, 1986); Hámor - Puskaporos Shelter Cave (Lambrecht 1912a, 1916, 1933, Jánossy 1977, 1986); Kesztölc - Bivak Cave (Hungary) (Jánossy 1977, 1986). Finds from Europe outside the Carpathian Basin: Q3: Azerbaijan, Czech Republic, France; Q4: Austria, Croatia, Czech Republic, France, Georgia, Germany, Greece, Italy, Moldova, Poland, Russia, Spain, United Kingdom (Tyrberg 1998);

\section{- Falco rusticolus (Linnaeus, 1758)}

Known from the Carpathian Basin Q3/II: Vindija (Croatia) (M. Malez 1961, V. Malez 1973, 1988, 1991, Malez \& Rukavina 1979); Q4/I: Bajót - Hóman Cave (Jánossy 1977, 1986); Tatabánya - Szelim Cave (Hungary) (Jánossy 1977, 1986); Detrekőszentmiklós Pálffy Cave (Dzeráva Skála - Plavecky Mikulas, Slovakia) (Lambrecht 1913, 1933). Finds from Europe outside the Carpathian Basin: Q3: Czech Republic; Q4: Czech Republic, France, Germany, Italy, Spain (Tyrberg 1998);

\section{- Falco columbarius (Linnaeus, 1758)}

Known from the Carpathian Basin Q1: Betfia 9 (Kessler 1985, Gál 2002a); Q1-2: Betfia 7, „Aven” (Kessler 1975, Jánossy 1977, Gál 2002a); Q3/I: Betfia 7/4 (Kessler 1975, Jánossy 1977, Gál 2002a); Q3/II: Süttő 1-4. (Jánossy 1977, 1986); Q4/I: Budapest-Remetehegy Shelter Cave (Kormos 1914, Lambrecht 1933, Jánossy 1977, 1986); Felsőtárkány - Peskő Cave (Lambrecht 1912b, 1933, Jánossy 1977, 1986); Hámor - Puskaporos Shelter Cave (Lambrecht 1912a, 1916, 1933, Jánossy 1977, 1986); Szilvásvárad - Istállóskői Cave (Lambrecht 1912b, 1933, Jánossy 1952, 1955, 1977, 1986); Tatabánya - Szelim Cave (Jánossy 1977, 1986, Varbó - Lambrecht Kálmán Cave (Hungary) (Jánossy 1977, 1986); Măgura Valea Coacăzei (Măgura-Peştera din Valea Coacăzei, Romania) (Gál 2002a); Detrekőszentmiklós - Pálffy Cave (Dzeráva Skála - Plavecky Mikulas) (Lambrecht 1913, 1933); Óruzsin - Antal Cave (Oruzer, Slovakia) (Nehring 1880, Róth 1881, Lambrecht 1912, 1933); Q4/ II: Körösbánlaki Cave (Peștera din Bălnaca, Romania) (Kessler 1982). Finds from Europe outside the Carpathian Basin: Q3: Czech Republic, France, Germany, Italy, Ukraine; Q4: Croatia, Czech Republic, France, Georgia, Germany, Italy, Poland, Spain, Ukraine, United Kingdom (Tyrberg 1998);

\section{- Falco naumanni (Fleischer, 1818)}

Finds from Europe outside the Carpathian Basin: Q3: France, Spain; Q4: Austria, France, Georgia, Greece, Italy, Russia, Spain, Ukraine (Tyrberg 1998);

\section{- Falco eleonarea (Géné, 1839)}

Finds from Europe outside the Carpathian Basin: Q3: France, Italy; Q4: France, Greece, Italy, Spain; (Tyrberg 1998);

\section{- Falco sp. foss. indet.}

Known from the Carpathian Basin MN 13: Polgárdi 4 (Hungary) (F. cf. cherrug size) (Kessler 2009); MN 15: Beremend 26 (Hungary) (F. cf. peregrinus size) (Kessler 2009);

\section{- Falco sp.}

Known from the Carpathian Basin Q1: Betfia 9 (Romania) (Kessler 1985, Gál 2002a); Q1-2: Betfia 7 (Romania) (Kessler 1975, Jánossy 1977a, Gál 2002a); Q2: Kiskóh - Bear's Cave (Chișcău - Peștera Urșilor, Romania) (Kessler 1982, Jurcsák \& Kessler 1988, Gál 2002a); Q3/I; Berfia 7/4 (Romania) (Kessler 1975, Jánossy 1977, Gál 2002a); Q4/I: Veternica (Croatia) (V. Malez 1973, 1988, Malez-Bačić 1975); Ohábaponor - Bordu Mare Cave 
(Ohaba Ponor - Peștera Bordu Mare, Romania) (Kessler 1985, Jurcsák \& Kessler 1988, Gál 2002a, 2003); Q4/II: Legény Cave (Hungary) (Lambrecht 1933); Kisderzsida (Derșida Mică) (Bindea 2008); Körösbánlaki Cave (Peștera din Bălnaca, Romania) (Kessler 1982). Finds from Europe outside the Carpathian Basin: Q4: Belgium, Bosnia - Hrzegovina, Bulgaria, France, Germany, Italy, Moldova, Montenegro, Poland, Russia, Spain, United Kingdom (Tyrberg 1998).

\section{Conclusions}

The family of eagles, vultures, buzzards and kites (Accipetridae) is well-represented in fossilized and subfossilized remains in the Carpathian Basin, as well as in the whole of Europe. Practically, every recent species is represented. Four extinct species, as well as two subspecies, were identified from the Quaternary (Gyps melitensis Lydekker, 1890; Gypaetus asiaticus Burchak-Abramovich, 1971; Aquila chrysaetos simurg Weeseie, 1987; Accipiter gentilis brachydactylus Mourer-Chauviré, 1975; Milvus brachypterus Jánossy, 1977 and Haliaeetus aff. angustipes Jánossy, 1983).

The family of falcons (Falconidae) is present with numerous species and rich fossilized and subfossilized material in the Carpathian Basin. They have a few problematic extinct species (Falco antiquus Mourer-Chauviré, 1975) and subspecies (Falco tinnunculus atavus Jánossy, 1972).

Regarding fossilized species from the family of ospreys (Pandionidae), apart from the one found in Máriahalom, only two have been described previously: Pandion homalopteron (Warter 1976), Pandion lovensis (Becker 1985). Pandion bones were also found in the lower Oligocene material of the Fayum site in Egypt (Eocene-Oligocene boundary, Priabonian-Rupelian, approx. 30 million years) Thus, the find from Máriahalom is the fourth of its kind, as well as one of the earliest ones in the world.

\section{Acknowledgements}

The author wishes to express his deep gratitude to Mihály Gasparik for access to recent bird bone collection in the Natural History Museum of Hungary, to József Vuts and Lóránd Abos for the language revision. 


\section{References}

Becker, J. J. 1985. Pandion lovensis, a New Species of Osprey from the Late Miocene of Florida. - Proceedings of the Biological Society of Washington 98: 314-320.

Bindea, D. (ed.) 2008. Arheozoologia Transilvaniei in pre- si protoistorie [Transylvanian archaeozoology archaeozoology in Prae- and Protoistory]. - Trognost Cluj-Napoca (in Romanian)

Bocheński, Z. 1997. List of European fossil bird species. - Acta Zoologica Cracoviensia 40(2): 293-333.

Bökönyi, S. 1984. Animal husbandry and hunting in Tác-Gorsium [The Vertebrate fauna of the Roman Town in Pannonia]. - Akadémiai Kiadó, Budapest (in Hungarian)

Bökönyi, S. \& Jánossy, D. 1965. Szubfosszilis vadmadár leletek Magyarországon - Subfossile Wildvogelfunde aus Ungarn [Subfossil wild bird remians from Hungary]. - Vertebrata Hungarica 7: 85-99. (in Hungarian and German)

Brodkorb, P. 1964. Catalogue of fossil Birds, Part 2 (Anseriformes through Galliformes). - Bulletin of the Florida State Museum, Biological Sciences 8(3): 195-335.

Brodkorb, P. 1972. New discoveries of pliocene birds in Florida. - In: Voous, K. H. (ed.) Proceedings of the XV. International Ornithological Congress, Abstract, p. 634. Leiden

Čapek, V. 1917. A püspökfürdői preglaciális madárfauna [The Preglaciale bird fauna from Püspökfürdö]. - Barlangkutatás 5: 66-74. (in Hungarian)

Fischer, K. \& Stephan, B. 1977. Vogelknochenfunde aus Quartären Ablagerungen Südwestrumaniens [Bird bones from Quaternary deposits in Southwest Romania]. - Annalen für Ornithologie 1: 79-90. (in German)

Gál, E. 2002a Avifauna pleistocenă a României [Pleistocene bird faunas of Romania - (Unpublied C.Sc dissertation)]. - Universitatea din Bucureşti, Facultatea de Geologie București (in Romanian)

Gál, E. 2002b Madárleletek a bajcsai várból [Bird finds from the Bajcsa Castle]. - In: Kovács, Gy. (ed.) Weitschawar - Bajcsa-vár, 101-105 + 4 ábra, Zalaegerszegi Múzeumok Igazgatósága, Zalaegerszeg (in Hungarian)

Gál, E. 2003. Bird remains from two Romanian caves: Curata Cave (Nandru) and Bordu Mare Cave (Ohaba Ponor). - ICAZ 2002. Abstracts, p. 56.

Gál, E. 2004. New evidence of fowling and poultry keeping in Pannonia, Dacia and Moesia during the period of the Roman Empire. - In: Gruppe, G. \& Peters, J. (eds.) Feathers, grit and symbolism. Birds and humans in the Ancient Old and New Worlds. - Proceedings of the $5^{\text {th }}$ Meeting of the ICAZ Bord Working Group, Munich, Germany, 26-30 July 2004. - Documenta Archaeobiologiae 3. Verlag Marie Leidorf GmbH.Rahden/ Westf., pp. 301-316.

Gál, E. 2005. Animal Remains from Archaeological Excavations in North-Eastern Hungary. - In: Gál, E., Juhász, I. \& Sümegi, P. (eds.) Environmental Archaeology in North-Eastern Hungary. - Varia Archaeologica Hungarica 19: $139-174$.

Gál, E. 2007a The Neolitic avifauna of Hungary within the context of the Carpathian Basin. - Antaeus 27: 273286.

Gál, E. 2007b Fowling in lowlands. Neolitic and Chalcholitic bird exploitation in South-East-Romania and the Great Hungarian Plain. - Archaeolinqua, Series Minor 24., Budapest

Gál, E. 2008. Faunal and taphonomic approach to a Late Pleistocene cavern bird bone assemblage in North-West Hungary. - Géobios 41: 79-90.

Hamar, M. \& Csák, K. 1969. Contribuţii la cunoaşterea faunei de vertebrate pleistocene din Dealul Burzău (com. Rîpa, jud. Bihor) - jung Wurm [Contribution to the knownledge of Pleistocene vertebrate fauna from Burzau Hill (Village Rîpa, Bihor County) - Lower Würm]. - Studii şi cercetări biologice Seria, Zoologie 21(6): 425432. (in Romanian)

Jánossy, D. 1952. Az Istállóskői barlang aurignaci faunája [The Aurignacian cave fauna from Istállóskő]. - Földtani Közlöny 82(4-6): 181-203. (in Hungarian)

Jánossy, D. 1960. Steinadler (Aquila chrysaetos L.) und Bartgeier (Gypaetus barbatus L.) aus dem Pleistozan Ungarns [Golden Eagle (Aquila chrysaetos L.) and Bearded Vulture (Gypaetus barbatus L.) from the Pleistocene of Hungary]. - Vertebrata Hungarica 2: 133-136. (in German)

Jánossy, D. 1962a Eine fossile Vogelfauna aus den Mosuterien-Schichten der Subalyuk-Höhle im Bükk-Gebirge [Fossil avifauna from the Mousterian layers of Subalyuk Cave in the Bükk Mountains]. - Aquila 67-68: 175188. (in German)

Jánossy, D. 1962b Vorlaufige Mitteilung über die Mittelpleistozäne Vertebratenfauna der Tarkö-Felsnische (NO-Ungarn, Bükk-Gebirge) [Preliminary notification of the Middle Pleistocene vertebrate fauna of the 
Tarkő Rock (NE Hungary, Bükk Mountains)]. - Annales Historico Naturales Musei Nationalis Hungarici 54: 155-176. (in German)

Jánossy, D. 1965. Fossiler Vogelfauna aus Mousterien Schichten der Curata-Hohle (Rumanien) [Fossil bird fauna from Mousterian layers of Curata Cave (Romania)]. - Vertebrata Hungarica 7(1-2): 106-116. (in German)

Jánossy, D. 1972. Middle Pliocene Microvertebrate fauna from the Osztramos Loc.1 (Northern Hungary). - Annales Historico Naturales Musei Nationalis Hungarici 64: 27-48.

Jánossy, D. 1974. Die mittelpleistozäne Vogelfauna von Hundsheim (Niederösterreich) [The Middle Pleistocene avifauna of Hundsheim (Lower Austria)]. - Sitzungsberichte der Österreichischen Akademie der Wissenschaften, Mathematisch-Naturwissenschftliche Klasse, Abteilung I. 182: 211-257. (in German)

Jánossy, D. 1976. Die Felsnische Tarkő und die Vertebratenfauna ihrer Ausfüllung [The cavity of Tarkő and the vertebrate fauna of Their Filling]. - Karszt- és Barlangkutatás 8: 3-106. (in German)

Jánossy, D. 1977. Plio-pleistocene bird remains from the Carpathian Basin. III. Strigiformes, Falconiformes, Caprimulgiformes, Apodiformes. - Aquila 84: 9-36.

Jánossy, D. 1981. Die altpleistozänen Vogelfaunen von Deutsch-Altenburg 2 und 4 (Niederösterreich) [The Early Pleistocene bird fauna of Deutsch-Altenburg 2 and 4 (Lower Austria)]. - Beiträge zur Palaontologie von Österreich 8: 375-391. (in German)

Jánossy, D. 1983. Lemming-remain from the Older Pleistocene of Southern Hungary (Villány, Somssich Hill 2.). - Fragmenta Mineralogica et Paleontologica 11: 55-60.

Jánossy, D. 1985. Wildvogelreste aus archaeologischen Grabungen in Ungarn (Neoliticum bis Mittelalter) [Wild bird remains from archaeological excavations in Hungary (from the Neoliticum to the Middle Ages)]. Fragmenta Mineralogica et Paleontologica 12: 67-103. (in German)

Jánossy, D. 1986. Pleistocene Vertebrate faunas of Hungary. - Akadémiai Kiadó, Budapest \& Elsevier, Amsterdam

Jánossy, D. 1987. Ältestpleistozäne vertebratenfauna von Beremend 15 (Sud-Ungarn) [Earliest Pleistocene vertebrate fauna of Beremend 15 ${ }^{\text {th }}$ (South Hungary)]. - Fragmenta Mineralogica et Paleontologica 13: 89-96. (in German)

Jánossy, D. 1992. Lower Pleistocene bird remains from Beremend (S-Hungary, Loc. 15. and 16.). - Aquila 99: 9-25.

Jánossy, D. 1995. A Late Miocene avifauna from Polgárdi, Western Hungary. - Acta Palaeornithologica, Courier Forschungsinstitut Senckenberg 181: 203-206.

Jurcsák, T. 1974. Prezenţa lui Gyps fulvus (Habl.) în cuaternarul României [The presence of Gyps fulvus (Habl.) in Romanian Queternar]. - Nymphaea 2: 169-184. (in Romanian)

Jurcsák, T. \& Kessler, E. 1986. Evoluţia avifaunei pe teritoriul României (I) [Evolution of the avifauna in the territory of Romania (I)]. - Crisia (16): 577-615. (in Romanian with English Summary)

Jurcsák, T. \& Kessler, E. 1988. Evoluţia avifaunei pe teritoriul României (III) [Evolution of avifauna on the territory of Romania (III)]. - Crisia (18): 647-688. (in Romanian with English Summary)

Kessler, E. 1974a Date noi asupra avifaunei fosile a Dealului Burzău - Râpa [New data to fossil bird fauna from Burzau Hill (Village Rîpa)]. - Nymphaea 2: 159-167. (in Romanian)

Kessler, E. 1974b Contribuţii noi la avifauna depozitelor hidrotermale postglaciare de la Băile 1 Mai - Oradea, jud. Bihor [New contributions to postglaciale avifauna and hydrothermal sediments from Băile 1 Mai Oradea, Bihor County]. - Tibiscus 11: 123-128. (in Romanian)

Kessler, E. 1974c Avifauna postglaciară de la Cuina Turcului, Cazanele Mari, România [Postglacial avifauna from Cuina Turcului, Cazanele Mari, România]. - Tibiscus 11: 113-122. (in Romanian)

Kessler, E. 1975. Contribuţii noi la studiul avifaunei fosile de la Betfia, jud. Bihor [New contributions to fossile avifauna from Betfia, Bihor County]. - Nymphaea 3: 53-59. (in Romanian)

Kessler, E. 1977. Avifauna postglaciară de la Vadu Crişului, jud. Bihor [Postglaciale avifauna from Vadu Crişului, Bihor County]. - Tibiscus 14: 255-260. (in Romanian)

Kessler, E. 1982. Avifauna fosilă şi subfosilă a Munţilor Apuseni [Fossil and subfossil bird fauna from Apuseni Mountains]. - Nymphaea 10: 171- 181. (in Romanian)

Kessler, E. 1985. Contribuţii noi la studiul avifaunelor cuaternare din România [New contributions to the study of Quaternary bird faunas in Romania]. - Crisia 15: 485-491. (in Romanian)

Kessler, J. 2009. Új eredmények a Kárpát-medence neogén és negyedidőszaki madár-világához, I. [New results with regard to the Neogene and Quaternary avifauna of the Carpathian Basin. Part I.]. - Földtani Közlöny 139(1): 67-82. (in Hungarian with English Summary) 
Kormos, T. 1913. Kleinere Mitteilungen aus dem ungarischen Pleistozän [Small releases from the Hungarian Pleistocene]. - Centralblatt für Mineralogie, Geologie und Palaontologie 1913: 13-17. (in German)

Kormos, T. 1914. Az 1913. évben végzett ásatásaim eredményei [The results of the excavations carried in the year 1913.]. - A Magyar Királyi Földtani Intézet 1913. évi jelentése, pp. 498-505., 531-540. (in Hungarian)

Kretzoi, M. 1954. Befejező jelentés a csákvári barlang őslénytani feltárásáról [Concluding report on the palaeontological exploration of Csákvár Cave]. - A Magyar Állami Földtani Intézet Évi Jelentése az 1952 évről, pp. 37-69. (in Hungarian)

Lambrecht, K. 1912a A borsodi Bükk fossilis madarai (Fossile Vögel des Borsoder Bükkgebirges) [Fossil birds of the Bükk Mountains from Borsod]. - Aquila 19: 270-287. (in Hungarian and German)

Lambrecht, K. 1912b Magyarország fossilis madarai - Die fossilen Vögel Ungarns [The Fossil birds of Hungary]. - Aquila 19: 288-320. (in Hungarian and German)

Lambrecht, K. 1913. Neueren Daten zur fossilen Ornis unseren Höhlen [Recent data for fossil birds in our caves]. - Barlangkutatás 1: 173 (in German)

Lambrecht, K. 1915. Fossilis nagy fülesbagoly (Bubo maximus Flemm.) és egyéb madármaradványok a magyarországi pleistocénből [Fossil's Big Eared Owl (Bubo maximus Flemm.) and other bird remains in Hungarian Pleistocene]. - Aquila 22: 177-187. (in Hungarian)

Lambrecht, K. 1916. Az első magyar preglaciális madárfauna - Die erste ungarische praglaziale Vogelfauna [The first Hungarian Preglaciale bird fauna]. - Aquila 22: 165-172. (in Hungarian and German)

Lambrecht, K. 1929. Mezozoische und tertiäre Vogelreste aus Siebenburgen [Mezozoic and Tertiary bird remains from Transylvania]. - In: Csiki, E. (ed.) X. Congres International de Zoologie, pp. 1262-1275. (in German)

Lambrecht, K. 1933. Handbuch der Palaeornithologie [Handbook of Palaeornithology]. - Gebrüder Borntraeger, Berlin, (in German)

Malez, M. 1961. Pecinska hijena iz indije kod Voce [The Cave Hyaenas come from Vindija Cave]. - Geologiceskij Vjesnik 14: 221-244. (in Croatian)

Malez, M. \& Rukavina, D. 1975. Kristurbacijske pojave u gornjopleistocenskim nasla-gama pecine Vindije kod Donje Voce u sjeverozapadnoj Hrvatskoj [Cristurbation appearance in Upper Pleistocene at Vindija Cave in Northwest Croatia]. - Rad Hazu knj. 371: 245-265. (in Croatian)

Malez, V. 1973. Fosilne ptice Jugoslavije [Fossil birds from Yugoslavia]. - Unpublished Dissertation, Zagreb University (in Croatian)

Malez, V. 1984. Paleornitološki ostaci iz kvartarnih naslaga nekih spilja Hrvatske i Slovenije [Paleornithological remains from the Quaternary Sediments of some Croatian and Slovenian caves]. - Deveti jugoslavenski speleoloski kongres, Zbornik predavanja, pp. 711-719. (in Croatian)

Malez, V. 1988. Pleistocenska ornitofauna iz spilje Vindije u sjevernozapadnoj Hrvatskoj [Pleistocene bird fauna from Vindija Cave in Northwestern Croatia]. - Rad Jugoslavenske Akademije Znanosti i Umjetnosti, Varazdin 2: 31-203. (in Croatian)

Mlikovskỳ, J. 1998. Early Pleistocene birds of Deutsch-Altenburg, Austria. - Acta Societatis Zoologicae Bohemicae 62: 135-141.

Mlikovskỳ, J. 2002. Cenozoic birds of the World, Part 1., Europe. - Ninox Press, Praha

Mlikovskỳ, J. 2009. Middle Pleistocene birds of Hundsheim, Austria. - Journal of the National Museum (Prague), Natural History Series 177(7): 69-82.

Mottl, M. 1938. Faunen, Flora und Kultur des ungarische Solutréen [Fauna, flora and culture of the Hungarian Solutréen]. - Quartär 1: 36-54. (in German)

Mottl, M. 1941. Die Interglazial- und Interglazialzeiten im Lichte der Ungarischen Saugetierfauna [Interglacial and interglacial times in the light of Hungarian mammalian fauna]. - Mitteilungen aus dem Jahrbucke der Königlich Ungarischen Geologischen Anstalt 35: 13-39. (in German)

Olson, S. L. 1985. The fossil record of birds. - Avian Biology 7: 80-252.

Olson, S. L. \& Rasmussen, P. C. 2001. Miocene and Pliocene biords from the Lee Creek Mine North Carolina. In: Ray, C. E. \& Bohaska, D. J. (eds.) Geology and Paleontology of the Lee Creek Mine, North Carolina, III. Smithsonian Contributions to Paleobiology 90: 233-365.

Pike-Tay, A., Bartosiewicz, L., Gál, E. \& Whitle, A. 2004. Body part representation and seasonility: sheep/goat, bird and fish remains from Early Neolitic Ecsegfalva 23 SE Hungary. - Journal of Taphonomy 2(4): 221-246.

Rabi, M. \& Botfalvi, Z. 2008. A preliminary report on the Late Oligocene vertebrate fauna from Máriahalom, Hungary. - In: Galácz, A. (ed.) $125^{\text {th }}$ Anniversary of the Department of Paleontology at Budapest University - A Jubilee Volume Hantkeniana 6: 177-185.

Randall, Z. S. 2012. https://www.floridamuseum.ufl.edu/florida-vertebrate-fossils/species/pandion-lovensis/ 
Rasmussen, D. T., Olson, S. L. \& Simons, E. L. 1987. Fossil Birds from the Oligocene Jebel Qatrani Formation, Fayum Province, Egypt. - Smithsonian Contributions to Paleobiology 62: 1-20.

Róth, S. 1881. Szepesmegye néhány barlangjának leirása [Descriptions of some caves in Szepes County]. - Mathematikai és Természettudományi Közlemények 16: 613-648. (in Hungarian)

Soergel, E. 1966. Die Vogelreste [The Bird Remains]. - In: Ehrenberg, K. (ed.) Die Teufels-oder Fuck-senlucke bei Eggenburg (NÖ) [The Devil or Fuck senlucke at Eggenburg (NA)]. - Denkschriften der Mathematisch-Naturwissenschftliche Klasse der Österreichischen Akademie der Wissenschaften, pp. 93-107. (in German)

Tyrberg, T. 1998. Pleistocene birds of the Palearctic: a catalogue. - Cambridge, Mass.: Nuttall Ornithological Club [Publications of the Nuttall Ornithological Club, No. 27.]

Warter, S. L. 1976. A New Osprey from theMiocene of California (Falconiformes, Pandionidae). - In: Olson, S. L. (ed.) Collected Papers in Avian Paleontology Honoring the $90^{\text {th }}$ Birthday of Alexander Wetmore. - Smithsonian Contributions to Paleobiology 27: 133-139.

Wettstein, O. V. \& Mühlhofer, F. 1938. Die Fauna der Höhle von Merkenstein in N-Ö [The fauna of the Merkenstein Cave in North Austria]. - Archiv Naturgeschichte, new series 7(4): 514-558. (in German)

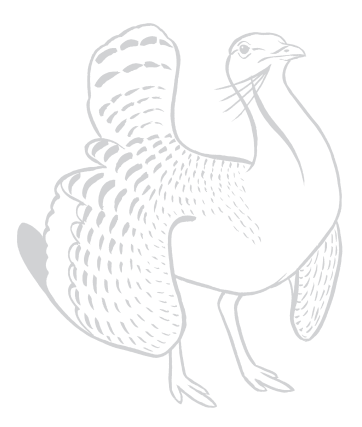

